\title{
Danuta Stawasz* \\ DETERMINANTS, LEVEL AND DYNAMICS OF THE SERVICE SECTOR DEVELOPMENT IN LODZ
}

\begin{abstract}
The paper aims to present changes in the structure of activities undertaken in Lodz, oriented towards the development of the service sector, including creative industries. A well-developed service sector provides a city and its residents with a long-term income increase and - in the case of Lodz - it creates opportunities to overcome industrial monoculture.

The paper will present the dynamics of the service sector development in Lodz during Poland's economic transformation. The conducted analysis will be based on the available statistical data. Many publications and reports related to the socioeconomic situation of the city will be also used for the purpose of the paper. Conclusions will allow to indicate the role and importance of the service sector in the city economy and to determine the competitive position of the city in the European dimension.
\end{abstract}

Keywords: services, creative industries, development of the city of Lodz.

\section{CITY AND ITS DEVELOPMENT}

Cities, as places of permanent human settlement, started to emerge with the beginnings of first civilisations and their multi-dimensional evolution throughout ages results from objective social and economic principles. All development processes take place in a particular time and spatial frame. "The basic forms of all being are space and time, and being out of time is just as gross an absurdity as being out of space" (Engels 1979: VII). A city is a habitat for an ever increasing population across the world and it also concentrates various forms of spatial development and human activity (Szymańska 2007: 8). Processes that take place in urban space result from the social division of labour and possibilities to meet one's needs in sectors other than agriculture. Individual groups in a given community perform different tasks meaning the organisation of social life varies internally. Multi-layer and multi-dimensional social, economic, legal, technical, environmental and spatial interdependences make finding an unambiguous definition of a city a hard task. However, wishing to attract attention to some determinants of a city we may quote the definition saying that a city is a place in space with the highest

\footnotetext{
* University of Lodz, Faculty of Management, Department of City and Regional Management.
} 
concentration of population and activities (trade, communication, manufacturing, services), which implies equally high intensity of economic, social, cultural technical, natural, innovation, administrative and political problems (Domański 1990: 55). This is a specific space where local community satisfies a considerable portion of its daily demand for various goods and services, which it purchases or manufactures, and acquires livelihood from different industries (Tundys 2008: 13). Contemporary cities, similarly to cities from past history, are places where people live and work performing various activities but the scale and scope of these activities vary. In ancient times cities were, first and foremost, the centres of power, which was not backed up with economic domination. Craftsmanship and trade, fundamentals of economic sphere, were of secondary importance. In centuries from $11^{\text {th }}$ to $13^{\text {th }}$ in Europe slow but significant economic progress was recorded, which stimulated the intensity of trade. Cities established in Roman times recover and new cities emerge on trade routes. A new European settlement network develops. Craftsmanship and trade provide an economic base in cities. Various factors contributed to the craftsmanship losing its importance in future centuries in favour of trade. In the period between the $16^{\text {th }}$ and the $18^{\text {th }}$ centuries, the guild system was little prone to market impulses, manufacturing was following consumption "step by step", there was no competition. It was restricted by regulations, such as: a ban on advertising, a ban on changing prices, regulated prices of raw materials, rationing work allowable in one workshop or specifying the upper production limit in one workshop (Kula 1983: 91).

The fall of feudalism changed the reality of economic development of states and, of course, cities. Merchants, who gained huge economic and political advantage, were interested in production organisation. Restrictions on production in cities, regulations prohibiting competition moved new production facilities to rural areas, where no restrictions existed. Later it will become the basis for industry and dynamic growth of urban centres. Industrial revolution, started in England at the end of the $18^{\text {th }}$ century, was the beginning of unlimited possibilities of developing industrial production. Rapid development of industry and changes in relationships in production related processes obviously contributed to dynamic growth of cities, when it comes to their number and size (Jewtuchowicz 1987: 101-105). Economic revolution, consisting in shifting from craft to industrial production, helped cities to develop as there was a need to concentrate production factors and a large number of workers around factories (Beaujeu-Garnier, Chabot 1971: 535). Income of both owners of companies and urban community increased. Effects of how cities operate depend on the ratio between basic, city-forming or non-basic, city-servicing functions. City-forming functions are decisive for the scale of exports, market production at the above-local level, information processing and distribution at a larger scale, and services to inhabitants outside of the city. The economic 
base of cities expanded, which had an impact on capital accumulation and using it for further development of businesses.

In the $19^{\text {th }}$ century population concentration in cities speeded up rapidly. It continued in the $20^{\text {th }}$ century and was still intensive at the beginning of the $21^{\text {st }}$ century. Cities expand and migration from rural to urban areas importantly influences the way urban communities operate. Industrialisation stimulates quick progress in urbanisation. These two phenomena create agglomerations: spaces of intensive industrialisation (city and its surrounding areas), with the city as a central space.

Each city evolves constantly. It evolves as an entity together with its sub-systems and relationships among them. A city emerges, flourishes, experiences crisis and decline, sometimes it parishes. Urban development is a continuous process. There is no target status which a city strives to achieve. Each stage is transitional, a starting point to another phase (Regulski 1980: 39). However, in each case there is a functionality or functionalities fundamental for activities and profitability. Their development is conditioned with both internal (e.g. labour resources, social capital, propensity to innovate, industrial traditions, attractive environment, natural resources, effective management of public affairs) and external factors (e.g. political circumstances, technological progress, tax system, state aid for businesses, labour law).

\section{SERVICES AND THEIR IMPORTANCE FOR CITY DEVELOPMENT}

The second half of the $20^{\text {th }}$ century was the time of new, breakthrough technical and technological developments. Progress in science translates into innovation (of process, product or organisation), improvements in technology, e.g. in engineering, biotechnology and, most of all, in IT (Jałowiecki 2006: 202). Economic globalisation changed the approach to how we assess value for money in business. At present such an assessment is made in the global scale unlike before when only national dimension was taken account of. In the last decade of the $20^{\text {th }}$ century some highly developed countries entered the post-industrial era of knowledge-based economy representing the following qualities:

- manufacturing and economic growth result from advancements in knowledge, innovation, information processing, universal access to new ideas and the burden of activities shifts from manufacturing to services,

- a new economic era gives higher status to professions where creativity is a major asset, information- and knowledge-based professions, while traditional, say industrial occupations, relatively loose in importance (Castells 1998: 242, quoted after Jałowiecki Szczepański 2006: 202). 
Changes in the economy lead to changes in proportions in functional structure of cities by modifying their employment profiles. Manufacture and industry gradually loose in importance in favour of services-related industries, including higher order services (Węcławowicz 2003: 62). O. Lange defined services as "any activity relating directly or indirectly (...) to the meeting of the needs of people, which, however, do not directly serve the manufacturing of products" (Lange 1967: 57). Significant role of services in the national and urban economy, their dynamic development result from the following premises:

- societies' becoming more wealthy and having more leisure time,

- increasing complexity of goods and services, which translates into the demand for specialist services (legal, advisory, training, financial, accounting, book-keeping, logistics, marketing, architecture and construction, etc.),

- increasing level of education followed by more interest in active leisure time offer connected with culture, tourism, leisure but also their links with health, education, safety, etc.,

- strong links between production and services in modern industries,

- development of transport, communication, telecommunications, IT technologies (Dochin, Oakland 1994: 9, quoted after Lotko 2009: 27).

The above premises should be supplemented with the free movement of capital across the world, development of large multinational corporations, global businesses, which force out the development of specific services and organisational standards as well as increasing migration flows across and beyond continents. These processes shape organisation formats for operators and migrants in the service sector. There are particular categories distinguished within the service sector, which are used in various analyses. Based on one of them we can identify the following types of services:

- distribution services including communication, transport, wholesale and retail trade,

- services to companies in all fields of the economy,

- public services rendered by public authorities (central and local government), which meet collective demand (e.g. safety, communication, education, healthcare, waste management, social welfare),

- personal services in individual consumption (e.g. entertainment, leisure, SPA, services to households) (see Sengelman, quoted after Jałowiecki, Szczepański 2006: 203).

European Classification of Economic Activities lists the following types of services:

- consumer services broken down into material (trade and repairs, hotels and restaurants, passenger transport and telecommunications, personal services, community services) and non-material (education, healthcare and social welfare, leisure and sports activities), 
- services to manufacturers and business: transport and warehouse management, financial intermediation, real estate services, renting of machinery and equipment, IT and related activities, R\&D works, other activities connected with business,

- general social services: public administration and defence, membership organisations, national organisations and teams.

Types of services presented according to the above classifications differ as a result of the adopted criterion but we may conclude, that their scope and relevance in the economy of each country cannot be overestimated for both business activity and for the inhabitants. For cities dynamic development of services means not only strengthening their economic base, new jobs, improved profitability of urban community, increased income of the city budget, better quality of life in the city but also the necessity to adapt buildings and infrastructure to what services need. Relative balance between city infrastructure and possibilities to execute income-generating functionalities is simply a precondition for development.

Nowadays, it is increasingly recognised that the dynamics of the city development is connected with creative industries. The sector of the national economy that consists of activities based on intellectual property, knowledge and culture is considered as the creative industries sector. This kind of activities include: advertising, publishing, photography, architecture, art market, radio and TV, film, music activities, arts and entertainment, programming, video games and computer games, design, arts and crafts, etc. Creative industries employ educated and enterprising young people, open to change and novelties, active in the labour market (see: Namyślak 2014: 447-452; Klasik 2011: 12; Tomczyk 2014: 12-15).

\section{LODZ - CITY DEVELOPMENT PROCESSES}

At the beginning of the $19^{\text {th }}$ century industrialists from all over Europe found a small settlement by the name of Lodz (situated ca. $140 \mathrm{~km}$ from Warsaw) an extremely attractive location for their capital. It was in the course of that very century when Lodz, with its surrounding towns and villages, turned into a huge agglomeration with textile industry as the major engine of its growth. Lodz is a city, which developed at a phenomenally rapid rate. At the beginning of the $19^{\text {th }}$ century its population was ca. $2 \mathrm{~K}$ inhabitants. By the end of the same century city population increased to ca. $300 \mathrm{~K}$ inhabitants and Lodz turned into an important European metropolis, globally famous as a centre of the textile industry (cotton and wool). The period of intensive development of the city as an industrial centre was connected with the decision of the government administration of 
the Kingdom of Poland, which designated it as a location for building factories. The decision was made in $1821^{1}$. The installation of the first steam machine in Geyer's factory in 1838 marked the beginning of the development of big capitalist-style industry and big industrial Lodz.

In the period between the wars, the textile industry was quickly rebuilt after the damages incurred during World War I. Already in the early 1920s new markets opened: Romania, Austria, Hungary and Czechoslovakia. In spring 1919 first weaving and spinning plants resumed their production.

As a result of predatory activities of the Nazi forces, Lodz textile industry suffered serious damages in the years 1939-1945. Although after the war modernisation took place and some resources were earmarked for investment in textile factories, the situation of the industry did not change significantly. It was still based on outdated and overexploited manufacturing equipment.

Qualitative breakthrough in Lodz industry took place in the 1970s. The then modernisation of the textile industry eliminated substantial technical delays. The dynamics of increase in capital assets and the degree to which technologies were updated in the leading industries achieved levels never experienced before. Unfortunately, modernisation and update process was never fully accomplished. Economic crisis of the 1980s disrupted all modernisation and investment processes $^{2}$, giving rise to economic and social problems in the city.

The economy of Lodz in the $19^{\text {th }}$ century and in the first half of the $20^{\text {th }}$ century represented all features of an open system with numerous international relationships. Lodz, as a big industrial city developed because foreign capital was invested here. It came together with German, Jewish and, to a lesser degree, Russian population. At that time the city was a real "Promised Land" to all investors. The capital came together with foreign patterns of production, manufacturing technology, work, organisation, mentality, culture, etc., which were adopted here. At that time Lodz was a global city with many economic links with foreign countries. Its industry used foreign raw materials and manufactured mainly for the needs and orders of foreign markets (first of all the Russian market) ${ }^{3}$.

Light industry (textile, apparel, footwear, knitting, accessories, technical articles) created Lodz as a city and the towns around it and for many years remained the main driving force of its development, giving jobs to local population and guaranteeing a satisfactory well-being. However, economic monoculture, the domination of one industry over the others is unfavourable to any city in the

${ }^{1}$ Jaskulski M. (1995), Stare fabryki Łodzi [Old Factories in Lodz], Towarzystwo Opieki nad Zabytkami [Ancient Monuments Society], Zora, Lodz, p. 5.

${ }^{2}$ Stawasz D. (1993), Ekonomiczne problemy rozwoju Lodzi [Economic Problems in the Development of Lodz], Part. I, "Przegląd Włókienniczy + Technik Włókienniczy”, no. 2, p. 32.

${ }^{3}$ Stawasz D. (2000), Współczesne uwarunkowania rozwoju polskich regionów [Contemporary Determinants of the Development of Polish Regions], published by the University of Lodz, Lodz, p. 207. 
long-run. When the industry is in crisis, it spills over to other economic activities of the city and produces far-reaching negative consequences. That was exactly the case of Lodz. Light industry factories bankrupted rapidly making machine and chemical plants, which worked for them, go out of business. Products manufactured here could not compete with foreign goods and the Eastern market stopped buying them at a scale recorded before. Lodz economic system broke down. For the population of the city it meant unemployment, lower income, lower standard of living and, from the point of view of public expenditure, increased budget spendings on benefits and lack of resources for activities aimed at alleviating negative phenomena (e.g. projects improving the attractiveness of Lodz as a destination for investors and residents).

In mid-1990s the economy started to slowly restructure based on endogenous resources (knowledge, skills, entrepreneurship, links with foreign partners, capital, manufacturing assets, buildings, internal demand). Transformations in Lodz and in the agglomeration did not result from any planned activities supported by the state but were effects of the mixture of market mechanisms, entrepreneurship of inhabitants, industrial traditions, general understanding of the need to work hard for relatively low remuneration, activities of "market environment" institutions, and efforts of local authorities, residents, local business people and foreign investors. Deep crisis of the 1990s, caused by the fall of the textile industry and companies from other industries working for it, led to structural crisis of the Lodz economy. One of direct contributors to the crisis was the absence of a well-developed service sector, in particular, higher order services (Stawasz 2000: 214). Nevertheless, 20 years of changes in all aspects of city operations helped overcome deep social and economic crisis, which started in the 1990s. Using its internal potential and undertaking steps to attract foreign capital, Lodz economy overcame the stage of depression, the monoculture of the textile industry and created the climate favourable for stimulating development. Economic structures were successfully transformed and a new diversified social and economic system was built. New economy of Lodz provides sound foundations for further development of the city as it is relatively crisis-resistant.

Below we list the reasons why Lodz managed to overcome the crisis and slowly enter into the next development stage:

- locating big shopping centres and various retail formats in Lodz and its surrounding areas (including famous "Manufaktura"),

- dynamic development of SMEs,

- dynamic development of the service sector (e.g. banking, legal, medical, real estate, finance, construction and renovation, IT, trade, education, leisure, catering, hotel, logistics, etc.),

- establishing of Lodz Special Economic Zone in 1997,

- opening of the airport, 
- development of wholesale textile markets in Rzgow, Tuszyn and Gluchow (ca. $20 \mathrm{~km}$ from Lodz),

- establishing of International Lodz Fair company,

- opening of the "Port Lodz" [Lodz Harbour] shopping centre with Ikea store in the Southern part of the city,

- development of the logistics centre in Strykow (ca. $20 \mathrm{~km}$ from Lodz).

Recently the structure of economic activities in Lodz got enriched with businesses from the so called creative sector (knowledge-intensive and creative activities) including advertising, architecture, fine arts, artistic craftsmanship, design and fashion, artistic and entertainment productions, publishing, software development, ICT development and services, financial services, legal services and other services for business (e.g. consulting, market research), R\&D, and higher education. All of the above economic activities are services or are pursued in collaboration with the service sector. What is important about the creative sector is the dependence of its effects on the human factor and the management of knowledge and skills. Moreover, the sector positively impacts the dynamics of social and economic development of the city.

It is also worth noting that the number of businesses in the creative sector in Lodz is in an upward trend. Also demand for services of these industries is increasing, most probably as a result of civilisation and educational progress. The share of creative businesses in the overall population of economic operators in Lodz between 2000-2010 increased more than twofold. In 2000 it was ca. 1.5\% and in 2010 more than 3.7\% (Przygodzki, Pożycka 2013: 194-195).

Clusters formation is the phenomenon connected with the development of economic structure in Lodz, which we can observe recently. Theoretically speaking, clusters are a specific form of organisation of industries, sectors and services within a concrete area (neighbourhood is an important aspect). They are developed to take over the advantages of localisation and in response to the fact that one type of production generates demand for other products. According to M.E. Porter, cluster is "a geographic concentration of related companies, specialised suppliers, service providers in a particular field and associated institutions (e.g. universities, standard setting agencies and their associations), which compete but also collaborate" 5 . Hence if a cluster emerges in a specific geographic area, economy, according to the principle of synergy, benefits from additional effects. Creative industries are supported by the Lodz Media Cluster formed by local companies from the media industry, film, TV, IT, ICT, universities and R\&D centres, local and

${ }^{4} \mathrm{Ca} .4 .5 \mathrm{~K}$ people work in the logistics and manufacturing centre in Strykow. According to the Book of Lists 2013 ranking of warehouse space in Poland, SEGRO Logistics Park Strykow is the second biggest logistics centre in Poland, quoted after Węzet autostradowy czyni cuda [Motorway Nod Does Miracles], Gazeta o inwestycjach, supplement to "Gazeta Wyborcza" daily, Warsaw 24 April 2014, p. 6.

\footnotetext{
${ }^{5}$ Porter M.E. (2001), Porter on competition, PWE, Warsaw.
} 
regional authorities, business and business environment institutions and organisations, and investors from the media sector. Media Cluster operates, e.g., in the field of promoting film industry in Lodz, conducting R\&D in new media technologies, and modernising and expanding production and post-production facilities ${ }^{6}$. Further dynamic development of the creative sector, with a substantial involvement of service providers, will surely contribute to the upgrading of living conditions and improving the competitiveness of the city.

Attention should be paid to what was outlined and implemented within the strategy of economic development of Lodz at the beginning of the $21^{\text {st }}$ century. The strategy identified three priority sectors representing the highest potential for the development of the city (cluster sectors). These are ${ }^{7}$ :

- BPO centres,

- logistics,

- household appliances industry.

Two first are connected with services and official documents produced by city authorities make references to the service sector, which should be considered vital for the Lodz economy. Another strategic document lists BPO, logistics and household appliances as priority industries and additionally mentions retail trade, real estate services and services to businesses as auxiliary industries and software development, and biotechnology as innovation industries ${ }^{8}$. Also here the service sector features prominently.

"Investors call contemporary Lodz a city of opportunities, where modern services and new industries develop in parallel: business service centres (BPO and IT), household appliances industry, electronics and biotechnology" (Raport o stanie miasta... 2013: 8).

In the business service sector in Lodz there are many operators, who, by their activities, positively impact the competitiveness of the city. Infosys company, with an increasing array of accounts clearing and accounting services and more and more new jobs, is one of the examples. The IT sector is developing intensely. Evidence can be found in the experience of HR Partners company and in statistical data. By the end of 2011 in the region there were 82 IT companies with the employment exceeding 9 people?

${ }^{6}$ Łódź w liczbach 2007 (2007) [Lodz in Numbers 2007], Lodz City Office, Office of Statistics in Lodz, Lodz.

${ }^{7}$ See Strategia rozwoju klastra $w$ Lodzi i planowane jej wdrożenie (2005) [Cluster Development Strategy and Its Planned Implementation], Lodz City Office, Lodz; Mertl J., Skowronski S. (2006), Łódzki klaster przedsiębiorczości - szanse na wzrost gospodarczy [Lodz Enterprise Cluster - Economic Growth Opportunities], [in:] Innowacje i przedsiębiorczość dla przyszłości [Innovation and Enterprise for the Future], SOOIPP Annual 2006, Lodz-Poznan-Warsaw-Wroclaw.

${ }^{8} \mathrm{http}: / /$ www.klasterlodzki.pl/pliki/Strategia_i_plan_wdrozenia.pdf.

${ }^{9} \mathrm{http}: / /$ lodz.gazeta.pl/lodz/1,35153,12331175,Firmy_informatyczne beda_wspolpracowac Powstaje_klaster.html\#ixzz2xZuiqxPQ. 
In the report drafted by the ABSL in 2013 "Sektor nowoczesnych usług biznesowych w Polsce" [Sector of Modern Business Services in Poland] Lodz was included in the group of 5 major and the biggest BPO/IT centres in Poland. The increase in employment in the sector, the biggest since 2009, was also highlighted. The development is fuelled by access to universities and good collaboration between city authorities and representatives of service centres.

British company Tate \& Lyle located its Global Shared Service Centre in Lodz in 2011. The Lodz branch supports business processes of the company in the field of IT, finance and accounting. These are single examples of companies from the IT sector but many sources suggest this is the beginning of an IT cluster in Lodz. IT as a university course is very popular among secondary school graduates. Labour market needs both IT specialists with deep knowledge in the field and beginners. IT jobs are among the most sought in the category of all technical jobs. Representatives of IT businesses claim the IT cluster is developing spontaneously but the impact of the Lodz University of Technology cannot be overlooked.

The development of logistics is connected with the junction of motorways A1 and A2 (North - South and West - East) situated not far from Lodz and the presence of logistics centre in Strykow. Eastern part of the city, Olechow, hosts the biggest re-loading railway station in Europe. It is also important for further development of logistics. Thus the agglomeration discounts its location in the centre of Poland, at European routes.

\section{SERVICE SECTOR STATISTICS FOR LODZ}

Data for Lodz from statistical yearbooks for 2000 and 2013 help us demonstrate the increase in importance of the service sector for the economy of the city in a dynamic approach. The data unambiguously confirm that services have a more and more positive impact upon economy. They also contributed to overcoming economic monoculture of the city dominated with the textile industry ${ }^{10}$.

${ }^{10}$ The Regulation of the Council of Ministers of 24 December 2007 on the Polish Classification of Activities (PKD) changed the rules on reclassification (acc. to PKD) of activities of business entities included in the National Official Register of National Economy Entities called the "REGON Register". Thus, it changed the way and methodology of keeping and updating the register of the national economy entities and, consequently, statistical data sets. Therefore, comparability of certain categories of data in the long-term perspective is impossible. See: the Regulation of the Council of Ministers of 24 December 2007 on the Polish Classification of Activities (PKD), Journal of Laws of 2007 No. 251, item 1885 and of 2009 No. 59, item 489. 
Persons employed in the national economy in Lodz in 1999-2007

\begin{tabular}{|c|c|c|c|c|c|}
\hline \multirow[b]{2}{*}{ Item } & \multicolumn{2}{|c|}{1999} & \multicolumn{2}{|c|}{2007} & \multirow{2}{*}{$\begin{array}{c}\text { Dynamics of } \\
\text { change } 2007 \\
(\%) 1999= \\
100 \%\end{array}$} \\
\hline & Total & $\begin{array}{l}\text { Structure } \\
(\%)\end{array}$ & Total & $\begin{array}{c}\text { Structure } \\
(\%)\end{array}$ & \\
\hline Total & 228828 & 100 & 219026 & 100 & 95.7 \\
\hline $\begin{array}{l}\text { Agriculture, } \\
\text { hunting and } \\
\text { forestry }\end{array}$ & 631 & 0.2 & 538 & 0.2 & 82.3 \\
\hline Industry & 69216 & 30.2 & 56831 & 25.9 & 82.1 \\
\hline Construction & 12380 & 5.4 & 7760 & 3.5 & 62.7 \\
\hline $\begin{array}{l}\text { Trade and } \\
\text { repair }\end{array}$ & 29288 & 12.8 & $32 \quad 189$ & 14.9 & 109.9 \\
\hline $\begin{array}{l}\text { Hotels and } \\
\text { restaurants }\end{array}$ & 2304 & 1.0 & 3004 & 1.4 & 130.4 \\
\hline $\begin{array}{l}\text { Transport, } \\
\text { storage and } \\
\text { communica- } \\
\text { tion }\end{array}$ & 15559 & 6.8 & 14686 & 6.7 & 94.4 \\
\hline $\begin{array}{l}\text { Financial in- } \\
\text { termediation }\end{array}$ & 12854 & 5.6 & 8364 & 3.8 & 65.1 \\
\hline $\begin{array}{l}\text { Real estate, } \\
\text { renting and } \\
\text { business } \\
\text { activities }\end{array}$ & 17058 & 7.5 & 28386 & 12.9 & 166.4 \\
\hline Others & 69544 & 30.5 & 67268 & 30.7 & 96.7 \\
\hline
\end{tabular}

Note: the data for the year 1999 - as of 30 September, excluding entities of natural persons employing less 9 persons. For the year 2007 - as of 31 December, the data concern economic entities employing more than 9 persons and public sector entities, regardless of the number of employees, based on the actual workplace, regardless of the position of the parent unit (excluding individual farmers).

Source: the author's own calculations based on the data included in Statystyka Lodzi 2000 (2000) [Lodz Statistics 2000], Statistical Office in Lodz, Lodz, p. 129, Statystyka Lodzi 2008 (2008) [Lodz Statistics 2008], Statistical Office in Lodz, Lodz, p. 160-161.

In 1999 in Lodz 228.828 people were employed in national economy, including 69.216 in industry. The numbers for 2010 were respectively 230.983 (55.191 in industry) and 225.607 (51.588 in industry) in the following year. Analysing the data from table 1 and table 2 we can clearly see that employment in industry diminishes in favour of the service sector. Percentage share of the employed in individual sections of business activities (ECA - European Classification of Activities) for 1999 and 2007 is shown in table 1. 


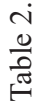

\begin{tabular}{|c|c|c|c|c|c|c|c|c|c|c|}
\hline \multicolumn{2}{|c|}{ 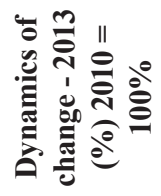 } & \multirow{2}{*}{$\begin{array}{l}\text { No } \\
\infty \\
8\end{array}$} & \multirow{2}{*}{$\begin{array}{l}\stackrel{+}{\infty} \\
\stackrel{\infty}{1} \\
\\
\stackrel{0}{0}\end{array}$} & \multirow{2}{*}{$\begin{array}{l}\infty \\
\text { à } \\
\\
\\
0 \\
\dot{i}\end{array}$} & \multirow{2}{*}{$\begin{array}{l}m \\
\tilde{a} \\
\infty \\
\vdots \\
\vdots\end{array}$} & \multirow{2}{*}{$\begin{array}{l}\tilde{a} \\
\tilde{n} \\
\ddot{n}\end{array}$} & \multirow{2}{*}{$\begin{array}{l}\stackrel{5}{a} \\
\stackrel{ \pm}{ \pm}\end{array}$} & \multirow{2}{*}{$\begin{array}{l}\infty \\
\stackrel{\infty}{0} \\
\text { n? }\end{array}$} & \multirow{2}{*}{$\begin{array}{l}\stackrel{9}{0} \\
\vdots \\
\because\end{array}$} & \multirow{2}{*}{ 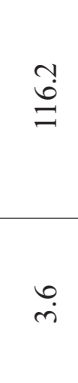 } \\
\hline & 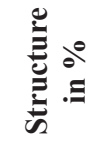 & & & & & & & & & \\
\hline 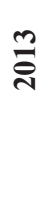 & हैं & 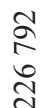 & ஓे & $\begin{array}{l}\underset{N}{N} \\
\vec{n}\end{array}$ & $\begin{array}{l}\stackrel{n}{q} \\
\& \\
q\end{array}$ & 守 & $\begin{array}{l}\text { o } \\
\text { q } \\
\text { m }\end{array}$ & $\begin{array}{l}\stackrel{2}{\alpha} \\
=\end{array}$ & $\frac{m}{\vec{m}}$ & $\overrightarrow{\hat{\sigma}}$ \\
\hline \multirow{2}{*}{ 극 } & 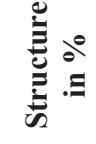 & 8 & $\overrightarrow{0}$ & $\stackrel{\stackrel{\sim}{i}}{\stackrel{\sim}{N}}$ & $\stackrel{n}{2}$ & $\vec{r}$ & $\begin{array}{l}\circ \\
\stackrel{ \pm}{J}\end{array}$ & $\begin{array}{l}n \\
n\end{array}$ & $\stackrel{\nabla}{-}$ & $\ddot{m}$ \\
\hline & $\stackrel{\bar{\pi}}{\stackrel{\tilde{\theta}}{\theta}}$ & 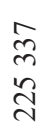 & $\hat{a}$ & 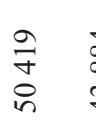 & $\begin{array}{l}\vec{D} \\
\infty \\
\infty \\
q\end{array}$ & $\begin{array}{l}\stackrel{0}{0} \\
\infty \\
\infty\end{array}$ & $\begin{array}{l}\text { \&े } \\
\text { ñ }\end{array}$ & $\begin{array}{l}\hat{n} \\
\stackrel{y}{y}\end{array}$ & $\stackrel{n}{\Rightarrow}$ & $\stackrel{n}{\approx}$ \\
\hline \multirow{2}{*}{$\overline{\bar{~}}$} & 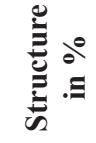 & 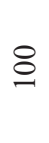 & $\overrightarrow{0}$ & તે & $\stackrel{\infty}{\stackrel{一}{2}}$ & $\begin{array}{l}\ddot{\varphi} \\
\dot{\rho}\end{array}$ & $\stackrel{\vartheta}{\dot{J}}$ & mis & $\stackrel{n}{-}$ & $\stackrel{\vec{r}}{\dot{r}}$ \\
\hline & $\stackrel{\overline{\tilde{\pi}}}{\stackrel{\tilde{\theta}}{\theta}}$ & 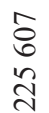 & ๙ે & $\begin{array}{l}\infty \\
\infty \\
i n \\
n\end{array}$ & $\begin{array}{l}\hat{a} \\
\text { 寸 }\end{array}$ & ¿্స & $\begin{array}{l}\infty \\
0 \\
m \\
m\end{array}$ & $\begin{array}{l}0 \\
\infty \\
=\end{array}$ & $\stackrel{\hat{n}}{m}$ & : \\
\hline \multirow{2}{*}{ 를 } & 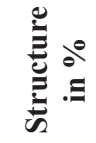 & \& & $\overrightarrow{0}$ & $\stackrel{\partial}{\hat{v}}$ & $\begin{array}{l}\infty \\
\stackrel{\ominus}{\ominus}\end{array}$ & $\dot{r}$ & $\stackrel{\vartheta}{ \pm}$ & $\begin{array}{l}0 \\
\text { in }\end{array}$ & $\dddot{m}$ & $\stackrel{0}{\circ}$ \\
\hline & हैं & 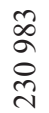 & $\frac{m}{m}$ & $\begin{array}{l}\bar{a} \\
n \\
n\end{array}$ & $\frac{\stackrel{?}{I}}{\stackrel{\infty}{+}}$ & $\frac{0}{6}$ & $\begin{array}{l}\hat{s} \\
\text { a } \\
\text { d }\end{array}$ & $\begin{array}{l}n \\
\approx \\
=\end{array}$ & $\hat{\text { s}}$ & 휴 \\
\hline & $\stackrel{\Xi}{\Xi}$ & సี & 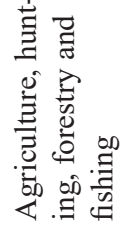 & 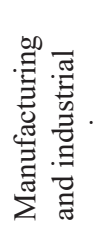 & 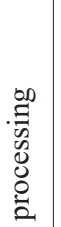 & 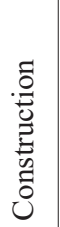 & 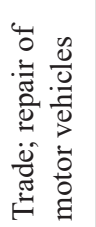 & 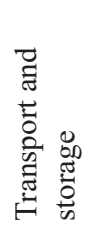 & 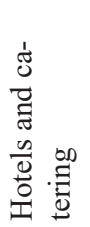 & 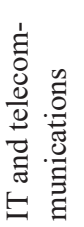 \\
\hline
\end{tabular}




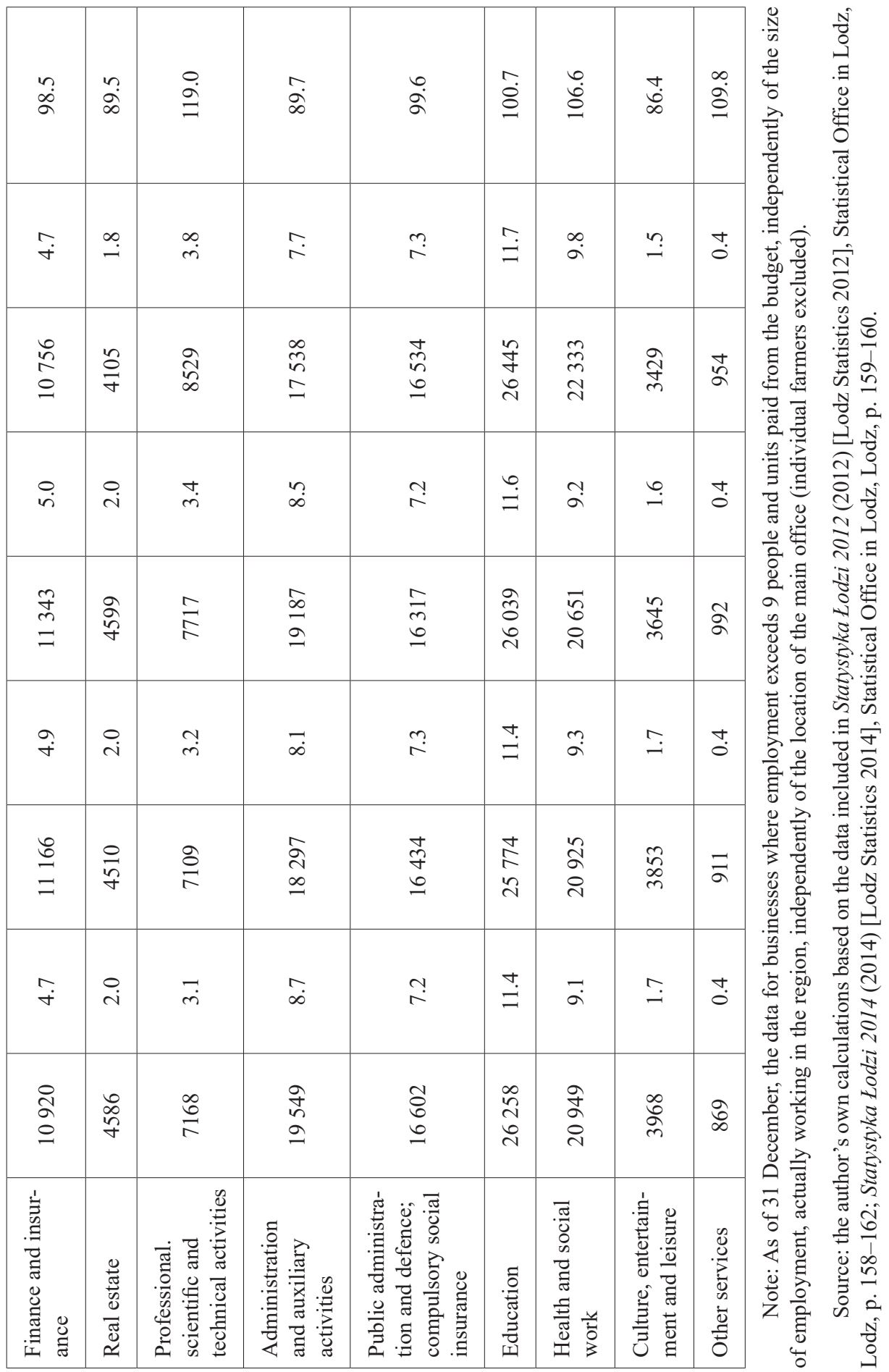


Statistical data on the number of employees in Lodz in the years 2010-2013 clearly indicate the growing importance of the service sector in the economy of the city. For the year 2010, the total number of employed persons was 304.642: trade, forestry, hunting and fishing -2.218 persons, industry and construction -81.923 persons, the total number of persons employed in services -219.601 persons. These figures for the year 2013 were as follows: the total number of employed persons was 299.615 , trade, forestry, hunting and fishing $-2,008$ persons, industry and construction -74.872 persons, the total number of persons employed in services -222.735 . The number of people employed in services during this period increased by 3.134 persons, which represents a percentage increase of $1.4 \%{ }^{11}$. The structure of employment in Lodz by sector in the years 2010-2013 is presented in table 1, the data in this case do not include persons working in entities employing up to 9 people.

Data in table 2, in accordance with the information of the Statistical Office in Lodz (see comment below the table), refer to businesses which employ more than 9 people and units paid from the budget, independently of the size of employment, working in the region no matter where their principal office is located. That is why statistics disregard small service providers, such as hairdressers, beauticians, dentists, veterinarians, garages, household appliances repair workshops, clothes repairs and renovation, IT businesses, accounting firms, landscape architects, cleaning and transport companies, etc. Thus the number of people employed in services is reduced, which is important for the assessment of the importance of the sector for the economy of the city. New jobs index is calculated as a relation between newly employed in a given year to the overall number of people working full time in the previous year as at 31 December. In 2011 the index for services was higher than for industry. That confirms the growing importance of services in Lodz, compared to manufacturing.

Statistics showing the changes in the economic structure of Lodz oriented towards the development of services, taking into account changes in the number of business entities by economic activity in the second decade of the $21^{\text {st }}$ century, is presented in table 3 .

Table 3

Entities of the national economy in Lodz in the years 2010-2013

\begin{tabular}{|c|c|c|c|c|c|}
\hline \multirow[b]{2}{*}{ Item } & \multicolumn{2}{|c|}{2010} & \multicolumn{2}{|c|}{2013} & \multirow{2}{*}{$\begin{array}{c}\text { Dynamics of } \\
\text { change }(\%)- \\
20132010=100 \%\end{array}$} \\
\hline & Total & $\begin{array}{c}\text { Struc- } \\
\text { ture }(\%)\end{array}$ & Total & $\begin{array}{c}\text { Struc- } \\
\text { ture (\%) }\end{array}$ & \\
\hline 1 & 2 & 3 & 4 & 5 & 6 \\
\hline Total & 304642 & 100 & 299615 & 100 & 98.3 \\
\hline
\end{tabular}

\footnotetext{
${ }^{11}$ BDL - Local Data Bank.
} 


\begin{tabular}{|l|c|c|c|c|c|}
\hline \multicolumn{1}{|c|}{1} & \multicolumn{1}{|c|}{2} & \multicolumn{1}{c|}{3} & 4 & 5 & 6 \\
\hline $\begin{array}{l}\text { Agriculture, hunting, for- } \\
\text { estry and fishing }\end{array}$ & 2218 & 0.7 & 2008 & 0.7 & 90.5 \\
\hline Industry and construction & 81923 & 26.9 & 74872 & 24.9 & 91.4 \\
\hline $\begin{array}{l}\text { Trade; repair of motor vehi- } \\
\text { cles, transport and storage, } \\
\text { hotels and catering, IT and } \\
\text { telecommunications }\end{array}$ & 87431 & 28.7 & 86527 & 28.9 & 99.0 \\
\hline $\begin{array}{l}\text { Finance and insurance, real } \\
\text { estate }\end{array}$ & 18909 & 6.2 & 18373 & 6.2 & 97.2 \\
\hline Other services & 114161 & 37.5 & 117835 & 39.3 & 103.2 \\
\hline
\end{tabular}

Source: the author's own calculations based on the data obtained from the Statistical Office in Lodz.

The first decade of the $21^{\text {st }}$ century witnessed the growth of market services sector as a response to increasing demand for such services. New hotels opened (in 1999 - there were 18 hotels offering 2.115 beds; in 2011 - 24 hotels and 3.848 beds), restaurants (at present more than 600 in Lodz), function halls, big shopping centres and retail malls, cinemas offering 50\% more places in 2011 compared to 2000 .

Services for business employ ca. 120K people in Poland. They offer jobs mainly to young university graduates. Polish metropolis are homes to numerous business service centres with foreign capital. In Krakow there are almost $30 \mathrm{~K}$ people working in them, $25 \mathrm{~K}$ in Warsaw another $25 \mathrm{~K}$ in Wroclaw. Lodz ranks fourth, together with the Three City, with the employment of ca. $15 \mathrm{~K}$. Such a business requires appropriate office space but also the availability of catering, leisure and cultural offer, good transport connections, educational opportunities for children in international schools ${ }^{12}$. Lodz recently expanded its offer of office space. Hence we may also conclude that business related services are on the rise.

\section{CONCLUSIONS}

Recent years for Lodz were the time of considerable development of public and market services. The scale and scope of the phenomenon are still not fully up to the requirements and needs of a big city such as the capital of the Lodz region with the population exceeding 2.5 mio. Gaps in this area significantly restrict the development of the city and of the region opening up, at the same time, opportunities for potential investors. These services include specialised financial, insurance,

\footnotetext{
${ }^{12}$ Centra usług kuszą inwestorów [BPOs Tempt Investors], Gazeta o inwestycjach, supplement to "Gazeta Wyborcza”, Warsaw 24 April 2014, p. 16.
} 
IT, telecommunications, stock exchange, forwarding, warehousing, hotel, catering, exhibition, conference, medical, educational and training activities connected also with training managers for high-tech industries. These services generate high income for the providers but also for the city budget and improve financial standing of local economy.

The authorities as well as inhabitants of Lodz are working to create a new image of Lodz as a creative and cultural city. The process of building and implementing development strategies and the creation of a new brand of the city takes into account the promotion of creative industries. Great emphasis is put on creating places where this kind of activity will thrive (e.g.: Off Piotrkowska, WI-MA Alternative Art Space, support for IT, premises for creative activity along Piotrkowska) and on supporting the organisation of original and innovative events (e.g.: Live Move Festival, the creation of murals, FashionPhilosophy Fashion Week Poland). The potential in this regard is huge, from industrial and architectural traditions of the nineteenth-century city, through the use of arts academies, the University of Lodz, Lodz University of Technology, the University of Medical Sciences and the media cluster to fair and exhibition activities, as well as events of national importance. If we take into account the definition developed by the consulting firm Kern European Affairs for the European Commission, according to which the creative industry can be divided into: the cultural sector (traditional art and cultural industries producing an artistic outcome) and the creative sector (which consists of industries and activities that use culture as a value added in manufacturing non-cultural products, it can certainly be said that Lodz, due to the enhanced support for these two sectors in the recent years merits the name: "Lodz - the City of Creative Industries"13.

Big cities in Poland, not only Lodz, suffer from the lack of services addressed to sick and elderly people. Increasing welfare of Lodz residents will increase demand for such services, in particular when our life span extends and young people at the working age leave the country in search for better income. Generation 65+ in the nearest future should have access to appropriate services that improve the quality of life. This is the niche which should be explored and filled out by public authorities. Lodz inhabitants are an aging population and we lack domestic patterns and experiences in assisting sick, disabled and elderly people.

For some years already works have been going on in relation with the "New Centre of Lodz" project, which consists in regeneration of 90 hectares of the city centre. New urban plan with the market at its centre will create an attractive space used by the inhabitants as a meeting point or perfect location for outdoor events, such as concerts, shows and exhibitions. The space surrounding the market has been earmarked for new buildings, e.g., a festival and congress hall for $4 \mathrm{~K}$

13 "Newsletter przemysłów kreatywnych" (2013) [Creative Industries Newsletter], City of Lodz Office, no. 9/45. 
spectators, the Theatre of Sound, a library, etc. Old power and heat generating plant (EC1) will also be modernised, similarly to the railway station Lodz Fabryczna (the building of the station will be preserved and the station itself will be moved eastwards in relation to its present location). The outcome of the project will be a new functional city centre. In accordance with the assumptions of the programme, it will be public space accessible, safe and attractive for residents and visitors. Post-industrial and former railway areas will be regenerated and turned into areas available for investment. Other effects include the reinforcement of metropolitan and cultural functions and preservation of a vital part of the urban tissue of $19^{\text {th }}$ century city. When it comes to the implementation, the reconstruction of the power and heat generating plant and the construction of the new railway station are the most advanced. "EC1 regeneration and its adaptation for culture and arts-related purposes" is a part of the Indicative List of Individual Key Projects of the Lodz Province for the Operational Programme of the Lodz Voivodeship for $2007-2013^{14}$. Their completion will result in further transformations of the economic structure of the city and new facilities will provide the service sector with conditions favourable for its long-term dynamic development.

In the context of the above considerations, referring to creative industries and services' development, it is worth to note the opening of a creative incubator on $8^{\text {th }}$ May 2014. This is one more place where creative industries will receive professional business support and it is the first incubator of this kind in Poland. It is intended as a platform on which artistic and business ideas will be connected. The process will hopefully also be fostered by the fact that all the facilities are located in historic buildings of Carl Scheibler's former textile factory, located nearby Księży Młyn district in Łódź ${ }^{15}$.

\section{REFERENCES}

Beaujeu-Garnier J., Chabot G. (1971), Zarys geografii miast, PWE, Warsaw.

Domański R. (1990), Zasady geografii społeczno-ekonomicznej, PWE, Warsaw-Poznan.

Engels F. (1979), Dialectics of Nature, PWN, Warsaw.

Innowacje i przedsiębiorczość dla przyszłości (2006), SOOIPP Annual 2006, Lodz-Poznan-Warsaw-Wroclaw.

Jałowiecki B., Szczepański M.S. (2006), Miasto i przestrzeń, Scholar Publishing House, Warsaw. Jaskulski M. (1995), Stare fabryki Łodzi, Ancient Monuments Society, Zora, Lodz.

Jewtuchowicz A. (1987), Efekty zewnętrzne w procesach urbanizacji i uprzemysłowienia, Acta Universitatis Lodziensis, University of Lodz, Lodz.

${ }^{14}$ Information after: Nowy projekt EC1 Fundacji Łódzkiej (2009) [New EC1 Project of the Lodz Foundation], "Railway Newsletter" November-December, http://www.ec1lodz.pl/EC1,12.

${ }^{15} \mathrm{http}: / /$ www.miastoinnowacji.lodz.pl/art-inkubator-dla-przemyslow-kreatywnych_58,148. html. 
Klasik A. (2011), Kreatywne przemysty w kreatywnej aglomeracji, [in:] A. Klasik (ed.), Kreatywne przemysty - kreatywne aglomeracje, Committee for Spatial Economy and Regional Planning, Polish Academy of Sciences, Bulletin no. 246, Warsaw.

Kula W. (1983), Teoria ekonomiczna ustroju feudalnego, KiW, Warsaw.

Lotko A. (2009), Ocena jakości uslug w centrach kontaktu z klientem, PWN, Warsaw.

Łódź w liczbach 2007 (2007), Lodz City Office, Office of Statistics in Lodz, Lodz.

Namyślak B. (2014), Rozwój oparty o działalności twórcze - ujęcie teoretyczne. Charakterystyka podmiotów zaliczonych do działalności twórczych we Wrocławiu, [in:] K. Kuć-Czajkowska, M. Sidor (eds.), Miasta, aglomeracje, metropolie w nurcie globalnych przemian, Maria $\mathrm{Cu}-$ rie-Skłodowska University Press, Lublin.

"Newsletter przemysłów kreatywnych" (2013), City of Lodz Office, no. 9/45.

Nowy projekt EC1 Fundacji Łódzkiej (2009), "Railway Newsletter”, November-December.

Porter M.E. (2001), Porter on Competition, PWE, Warsaw.

Przygodzki Z., Pożycka P. (2013), Rozwój i zróżnicowanie sektora kreatywnego w Łodzi, "Studia Ekonomiczne Regionu Łódzkiego", PTE Lodz Branch, Lodz, no. IX.

Regulski J. (1980), Rozwój miast w Polsce, PWN, Warsaw.

Statystyka Łodzi 2000 (2000), Statistical Office in Lodz, Lodz.

Statystyka Łodzi 2012 (2012), Statistical Office in Lodz, Lodz.

Stawasz D. (1993), Ekonomiczne problemy rozwoju Łodzi, vol. I, "Przegląd Włókienniczy + Technik Włókienniczy", no. 2.

Stawasz D. (2000), Współczesne uwarunkowania rozwoju polskich regionów, Lodz.

Strategia rozwoju klastra w Lodzi i planowane jej wdrożenie (2005), Lodz City Office, Lodz.

Strategia Zintegrowanego Rozwoju Lodzi 2020+ (2013), Lodz City Office, Mayor's Department, Lodz, March.

Tomczyk M. (2014), Segment i sektor kreatywny w metropolii szczecińskiej, Kadruk Press, Szczecin. Tundys B. (2008), Logistyka miejska, koncepcje, systemy, rozwiazania, Difin, Warsaw.

Węcławowicz G. (2003), Geografia społeczna miast. Zróżnicowania społeczno-przestrzenne, PWN, Warsaw.

Regulation of the Council of Ministers of 24 December 2007 on the Polish Classification of Activities (PKD), Journal of Laws of 2007 No. 251, item 1885 and of 2009 No. 59, item 489.

http://www.klasterlodzki.pl/pliki/Strategia_i_plan_wdrozenia.pdf.

http://lodz.gazeta.pl/lodz/1,35153,12331175,Firmy_informatyczne_beda_wspolpracowac_Powstaje_klaster.html\#ixzz2xZuiqxPQ.

http://www.ec1lodz.p1/EC1,12. 